health depend more on the distribution of income within a population than its average level..$^{120}$ If this is true then making incomes more equal would be the most effective way of improving health. His research used data from nine developed countries, and his conclusions seem borne out by the experience in Britain during both world wars and in Japan since the early 1970s. (Japan now has the most equally distributed income in the world and the longest life expectancy.)

In this year's election campaign the Labour party proposed changing taxation to produce more equal disposable incomes - which may have lost it the election. The Conservative party promised further tax cuts and won. The outcome would not have surprised the American economist John Kenneth Galbraith, who, in a recent book, identifies a cluster of attitudes that characterise what he calls "the culture of contentment." 10 These include an affirmation by the contented majority that they are receiving their just deserts, a preference for short term public inaction to protective long term action, a belief in the need "to get the government off the backs of the people" (which translates to meaning less public spending), and a tolerance of great differences in income. Writing a few months before the riot in Los Angeles, he wondered whether those permanently denied escape from deprivation would react violently some day.

Britain may not have much breathing space in which to work out its salvation. Our summer riots are once again in full swing, with those on the bottom of the pile taking out their anger on the police. The government's avowed policy on public spending means that these people will be even worse off this time next year. On current trends, therefore, poverty is not about to get better but about to get worse.
Whether we act from altruism or self interest we must actbut what should be done? According to the Organisation for Economic Cooperation and Development, neither labour market policies, macroeconomic policies, education, training, nor social policies can on their own provide the answer. What is needed is a package of properly coordinated policies. ${ }^{2}$ It's time Britain had one.

TONY DELAMOTHE

Deputy editor, $B M \mathcal{F}$

I Moser K, Goldblatt P, Fox J, Jones D. Unemployment and mortality. In: Goldblatt P, ed. Longitudinal study: mortality and social organisation 1971-1981 England and Wales. London HMSO, 1991. (Series LS No 6.)

2 Organisation for Economic Cooperation and Development. Employment outlook. Paris: OECD, 1992.

3 Tagaza E. Australia confronts job crisis. Financial Times 1992 Jul 10:4 (col 1-5).

4 Lewis AM. Unemployment and health in Sweden. BMf 1992;305:269.

Lamont N. Oral aymers. House of Commons Offical Report (Hansard) 1991 May 16;191:col 413. (No 109.)

6 Department of Social Security. Households below average income: a statistical analysis 1979-1988/89. London: HMSO, 1992.

Huhne C. Pay gap "widest since 1886." Independent on Sunday 1991 Sept 29:3 (col 6).

8 Maude F. W'ritten answers. House of Commons Official Report (Hansard) 1991 May 9:190:col 552-4. (No 104.)

9 Hills J. Changing tax: how the tax system works and how to change it. London: Child Poverty Action Group, 1990.

10 Galbraith JK. The culture of contentment. London: Sinclair Stevenson, 1992.

11 Hulby M, Dix G. Evaluating the social fund. London: HMSO, 1992.

12 Dillner L. Social fund failing. BMJ 1992;305:138.

13 Willmott P, Hutchison R, eds. Urban trends I. London: Policy Studies Institute, 1992.

13 Willmott P, Hutchison R, eds. Urban trends $I$. London: Policy Studies Institute,
14 Tonks A. Fifteen years of deprivation: Britain's inner cities. BMF 1992;305:212.

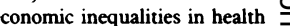
10 years on. $B M \mathcal{F} 1991 ; 301: 429-32$

16 Delamothe T. Social inequalities in health. BMJ 1991;303:1046-50.

17 Jacobson B, Smith A, Whitehead M. The nation's health: a strategy for the 1990s. London: King's Fund, 1991

18 Secretary of State for Health. The health of the nation: a strategy for health in England. London: HMSO, 1992. (Cm 1986.)

19 Quick A, Wilkinson R. Income and health. London: Socialist Health Association, 1991.

20 Wilkinson RG. Income distribution and life expectancy. BMF 1992;304:165-8.

\title{
Foodborne botulism
}

\section{New techniques for preserving foods bring the need for greater awareness of the risks}

Paralytic illness after the consumption of sausage (Latin botulus) was described in the early nineteenth century. The symptoms are caused by the ingestion of preformed neurotoxins produced by strains of Clostridium botulinum, an anaerobic Gram positive bacillus that forms spores.

Symptoms of botulism may develop within six hours of ingestion of the toxin; in most patients the latent period is 12-36 hours. Typically the muscles supplied by the cranial nerves are affected first, and disturbances of vision and difficulties with swallowing and speech may be followed by a descending paralysis that is bilateral but not necessarily symmetrical. The clinical presentation is varied and may be related to the toxin type; autonomic symptoms precede muscular weakness more commonly in intoxications with the type B strain.'

The diagnosis of botulism may rest on clinical and epidemiological grounds alone as supportive investigations may not yield definitive results. Electromyographic studies may show atypical response patterns, particularly early in the illness, and in two recent outbreaks a false positive response to edrophonium was found. ${ }^{23}$

Toxin may be undetectable in the blood, gastric washings, and faeces. The rarity of the illness and misdiagnosis of early cases have led to speculation that sporadic cases, particularly in people with mild illness, are overlooked. Evidence to support this surmise has not been forthcoming.

Patients suspected to have botulism should be observed in hospital and public health staff informed so that immediate inquiries into possible food sources can be pursued. The early warning system in the World Health Organisation's surveillance programme for control of foodborne infections and intoxications in Europe should ensure that international incidents of botulism are recognised. Most cases of botulism are associated with home preserved meats, fish, and vegetables, and the food affected is often idiosyncratic to a country and culture. ${ }^{4}$

Although all botulinum toxins are inactivated by heating at $80^{\circ} \mathrm{C}$ for 30 minutes, adequate processing and storage to prevent the production of toxin must be the primary objective of preserving food. Spores of all strains of $C$ botulinum are destroyed by heat at $121^{\circ} \mathrm{C}$ for two and a half minutes, but not all food is suitable for such heat treatment.

Production of toxin by proteolytic strains (all type A and some types $\mathrm{B}$ and $\mathrm{F}$ ) is inhibited below $\mathrm{pH} 4 \cdot 6$, in a salt $(\mathrm{NaCl})$ concentration of $10 \%$, and at temperatures below $10^{\circ} \mathrm{C}$, while the respective figures for non-proteolytic strains $\stackrel{D}{\circ}$ (type $\mathrm{E}$ and remaining types $\mathrm{B}$ and $\mathrm{F}$ ) are $\mathrm{pH}<5 \cdot 0,5 \% \mathrm{NaCl}, \stackrel{2}{2}$ and below $3 \cdot 3^{\circ} \mathrm{C} .{ }^{4}$ Commercially canned foods are subject to 8 high standards, and particular attention has been paid to low acid foods (that is, those with a pH $>4 \cdot 6$ ). Canned (or bottled) products such as cured meats rely on a reduced heat treatment $\rightleftharpoons$ to kill vegetative cells and salt and nitrite to inhibit the growth of $C$ botulinum spores. Acidic fruits $(\mathrm{pH}<4 \cdot 6)$ and acidified vegetables are subjected only to pasteurisation and depend on 
the low $\mathrm{pH}$ to inhibit production of toxin. In some fruits (for example, tomatoes) survival of aerobic spore bearers and yeasts may alter the $\mathrm{pH}$ and allow growth of $C$ botulinum spores, but this will be recognised by the container being blown. Salami and other dry fermented sausages are preserved by adding salt and nitrate and allowing ripening and drying to reduce the $\mathrm{pH}$ to $<5 \cdot 0$. An extensive review of the traditional methods of preserving foods observes that commercial products have an excellent safety record. ${ }^{4}$

The increasing use of modified atmosphere packaging and the dependence on refrigeration to extend the shelf life of raw meat, fresh fish, and several processed products without preservatives has stimulated interest in the risk of botulism from these products.

A modified atmosphere package is one in which a food product is stored in something other than air and includes vacuum packaging. ${ }^{5}$ This may result in an environment conducive to the growth of anaerobes, which, combined with the ability of non-proteolytic strains to grow at refrigeration temperature, has led to concern that toxin may be produced before spoilage is obvious to the consumer. ${ }^{6}$ Experimental studies have shown that the time taken for production of toxin varies with the atmosphere and the food. Efforts to quantify safe storage conditions for both raw meat and fish in modified atmospheres have been undertaken and predictive models devised..$^{78}$ Foods in modified atmosphere packaging have been available for several years in Europe and no cases of botulism have yet been attributed to their consumption. The possibility that ambient temperatures may be too high to inhibit toxin production, however, has led to calls for additional safety controls, including low dose irradiation, coinoculation with lactic acid bacilli, and heat treatment after packing.

Coleslaw prepared from shredded cabbage kept in modified atmosphere packaging has been associated with four cases of botulism, and subsequent inoculation studies showed that toxin could be detected within four days in the shredded cabbage. ${ }^{9}$ Toxin developed in mushrooms stored in sealed containers artificially contaminated with $C$ botulinum spores but was not produced if sufficient oxygen was present in the package. ${ }^{10}$ The Food and Drug Administration has advised that mushroom packaging should be pierced with air holes to prevent botulinum toxin forming. Similar measures with the packaging of all fresh vegetables would seem sensible.
The consumer demand for convenience foods with minimal or no preservative has led to the development of refrigerated processed foods with extended durability, and guidelines for studies to evaluate the risk of botulism in these products have been promoted. ${ }^{11}$ Workers studying the survival of $C$ botulinum in 11 such processed foods concluded that storing the product at or below $3.3^{\circ} \mathrm{C}$ was the single most important safety factor but questioned whether under retail and housekeeping conditions this was achievable. ${ }^{12}$ They also observed that recommended heating times for these foods before consumption could not be relied upon to inactivate botulinum toxin completely.

The application of hazard analysis of critical control points, a method of food hygiene risk assessment, to the production of refrigerated processed foods with extended durability and adequate labelling to distinguish them from apparently similar but more stable products are essential. ${ }^{13}$ The development of reliable, consumer friendly time-temperature indicators for refrigerated processed foods with extended durability and fresh foods in modified atmosphere packaging would do much to ensure customer confidence in these products. ${ }^{14}$ Foodborne botulism is a preventable illness.

Director,

D N/HUTCHINSON

Public Health Laboratory,

Royal Preston Hospital,

PrestonPR2 4HG

1 Critchley EMR, Mitchell JD. Human botulism. Br $\mathcal{f}$ Hosp Med 1990;43:290-2.

2 Critchley EMR, Hayes PJ, Isaacs PET. Outbreak of botulism in north west England and Wales, June 1989. Lancet 1989;ii:849-53.

3 St Louis ME, Peck SHS, Bowering D, Mogan GB, Blatherwick J, Baneriee S, et al. Botulism from chopped garlic: delayed recognition of a major outbreak. Ann Intern Med 1988;108:363-8.

4 Hauschild AHW. Clostridium botulinum. In: Doyle MP, ed. Foodborme bacterial pathogens. New York: Marcel Dekker, 1989:111-89.

5 Farber JM. Microbiological aspects of modified-atmosphere packaging technology-a review. fournal of Food Protection 1991;54:58-70.

6 Stammen K, Gerdes D, Caporaseo F. Modified atmosphere packaging of seafood. Food Science and Nutrition 1990;29:301-31.

Lambert AD, Smith JP, Dodds KL. Shelf life extension and microbiological safety of fresh meat a review. Food Microbiology 1991;8:267-97.

8 Baker DA, Genigeorgis C. Predicting the safe storage of fresh fish under modified atmospheres with respect to Clostridium botulinum toxigenesis by modelling length of the lag phase of growth. Journal of Food Protection 1990;53:131-40.

9 Solomon HM, Kautter DA, Lilly T. Outgrowth of Clostridium botulinum in shredded cabbage at room temperature foumal of Food Protection 1990;53: 831-3.

10 Sugiyama H, Rutledge KS. Failure of Clostridium botulinum to grow in fresh mushroom packaged in plastic film overwraps with holes. Joumal of Food Protection 1978;41:348-50.

11 Doyle MP. Evaluating the potential risk from extended-shelf-life refrigerated foods by Clostridium botulinum inoculation studies. Food Technology 1991;45(4):154-6.

12 Notermans S, Dufrenne J, Lund BM. Botulism risk of refrigerated, processed foods of extended durability. Fournal of Food Protection 1990;53:1020-4.

13 Adams CE. Applying HACCP to sous vide products. Food Technology 1991;45:148-51.

14 Taoukis PS, Fu B, Labuza TP. Time-temperature indicators. Food Technology 1991;45:70-82

\section{Cytokines and cancer}

\section{Clinical trials and experimental studies are unravelling their paradoxes}

The cytokines, which include the interferons, tumour necrosis factor, and the interleukins, are a burgeoning and diverse family of peptide cell regulators. The availability of natural and recombinant cytokines has led to their use as antitumour agents and in limiting the myelosuppressive effects of cytotoxic chemotherapy. Their antitumour effects may be direct or indirect, disrupting the blood supply of tumours or stimulating immunological responses against tumours. They may also have other roles in the treatment of cancer, functioning as radiosensitisers, radioprotectors, and modulators of oncogene expression. Within the malignant process cytokine and cytokine receptors are disregulated, and cytokine produced by tumours may contribute to the pathophysiology of cancer.
The interferons are effective treatments of malignancy. In the chronic phase of chronic myeloid leukaemia treatment with interferon alfa has produced haematological remissions in up to $70 \%$ of patients and occasional reversions to a normal chromosomal state. Peripheral blood responses are reported in $80 \%$ of patients with hairy cell leukaemia. ${ }^{2}$ Responses to interferon alfa are also reported in patients with Kaposi's sarcoma (30\%), myeloma (10-20\%), carcinoid tumours $(40 \%)$, renal cell carcinoma $(5-20 \%)$, lymphoproliferative disorders (20-40\%), essential thrombocythaemia, and minimal residual disease after treatment for ovarian cancer. ${ }^{3}$ The possible synergy of interferon alfa with chemotherapy has been investigated in colorectal cancer with fluorouracil, ${ }^{4}$ in non-small cell lung cancer with cisplatin, ${ }^{5}$ and in melanoma 